\title{
TFEB Protein Overexpression
}

National Cancer Institute

\section{Source}

National Cancer Institute. TFEB Protein Overexpression. NCI Thesaurus. Code C154492.

Overexpression of TFEB protein that results from a $\mathrm{t}(6 ; 11)(\mathrm{p} 21 ; \mathrm{q} 12)$ translocation, which involves the human genes MALAT 1 and TFEB and is associated with renal cell carcinoma with $\mathrm{t}(6 ; 11)(\mathrm{p} 21 ; \mathrm{q} 12)$; MALAT 1-TFEB. 